\title{
The Legal Dilemma of Private Equity Fund Financing in China and Its Response
}

\author{
${ }^{1}$ Cardiff and Vale College Changzhou, Changzhou, Jiangsu, China \\ ${ }^{2}$ University of York, Shanghai, China \\ *Corresponding author. Email: Yaqin_Xu@outlook.com \\ These authors contributed equally.
}

Jinwei Chao ${ }^{1, \dagger}$, Yaqin $\mathrm{Xu}^{2, *}{ }^{*} \dagger$

\begin{abstract}
According to the survey, the human capital fund has not become the main fund source of China's venture capital industry. The lack of RMB fund status will greatly affect the market share of domestic assets. But suppose there is a law regulating the financing of these funds and guiding them into the private equity fund market. In that case, it will greatly accelerate the development of equity investment funds in China. Therefore, the development of private equity funds is very important for China. At present, our country's legal system is in short supply in the development of equity funds. It is mainly reflected in the defects of the investor system of China's private equity companies, the single source of industry's capital, the structure that needs to be optimized and so on. The immaturity of these legal systems is mainly attributed to China's legal tradition - a policy first and law lag. In this long process, there have been problems such as insufficient supervision, lack of specific laws and regulations and vague legal provisions. Therefore, China should set up some new legal systems according to China's national conditions and the legal systems of developed countries in the private equity fund market to eliminate the predicament caused by the immaturity of the current legal system. Furthermore, we should strictly supervise private equity funds, and protect investors and prevent systemic financial risks. Given that qualified investors are the cornerstone of the private equity market, establishing the qualified investors' system is urgent. Among them, a qualified investor system and perfect supervision system should be set up firstly.
\end{abstract}

Keywords: China private equity, legal dilemma, investor system, approach to dilemma, the status of private equity

\section{INTRODUCTION}

The present growth of private equity investment funds in China is still in its early stages. The legislative framework and regulatory system have not yet been formed. At the same time, there is a shortage of mature institutional investors and brand fund managers, and exit pathways are not developed well. All of these issues should be addressed and investigated. In recent years, sustained economic growth in China has drawn a constant influx of private equity funds from throughout the world [1]. This leads to an increasing number of researches related to the developments and negative aspects of private equity in our country. This essay will firstly discuss the legal dilemma of private equity through four aspects. Then we evaluate the current situation of private equity funds, such as the imperfect investor system and imperfect regulatory system, to show the legal difficulties that need to be considered in the future.
Moreover, the paper will discuss the main reasons for the private equity funds' legal dilemma. Finally, some of the solutions would be suggested to solve the current issues in private equity in our country, including setting a system for qualified investors.

\section{PRIVATE EQUITY FUNDS' LEGAL DILEMMA}

\subsection{The status of private equity funds and legal nature are unclear}

In 2008, a total of 51 new private equity funds was established to invest in mainland China, with 30 funded in dollars and 20 funded in Yuan [2]. The $\$ 30$ funds raised a total of $\$ 394.79$ billion, which occupied $64.6 \%$ of the total amount raised. It could be shown that foreign currency funds continue to dominate China's private equity funds. Meanwhile, Funds raised in RMB account 
for 32.0 per cent of total funds raised in venture capital funds. This indicated that RMB funds still had not become the primary source of capital in China's venture capital industry and strongly relied on foreign capital. Because of the difficult entry of domestic funds, overseas funds accounted for a large proportion of the investment amount. There might be a lack of status of RMB funds in legal provisions, affecting the market share of domestic assets. Suppose there were laws governing fund-raising that directed these funds into the private equity market. In that case, it might help accelerate the development of equity investment in China.

\subsection{The current laws are not favourable to investors}

In the current situation, private equity funds can be financed by state-owned capital and private capital in our country [3]. The source of funds of local private equity funds in our country is single, and the structure needs to be optimized. Public financial institutions such as banks, insurance, or public corporations that are subject to applicable rules and regulations cannot completely expose their funds to the capital market. Individuals participating in real estate and equity investments are more likely to be influenced by asset price changes restricting the extent of private equity funds that may be invested in terms of private money. Compared with investment in European private equity, according to the figure published by European Private Equity and Venture Capital Association (EVCA), it showed that banks were the greatest single source of finance, accounting for roughly a third of all new funds raised in Europe in 2005 [4]. Then, the number of funds contributed by pension funds remains modest in comparison to their share of investment funds. In addition, unlike the United States, European pension funds have traditionally committed a low percentage of their assets to private equity. For instance, Barros argued that nearly half of all US venture funding came from pension funds between 1995 and 1999[5]. However, the growth of venture capital has been critical in encouraging. The National Social Security Fund began allowing equity investments in May 2008, with a maximum of $10 \%$ of the amount of the social security fund's management funds, which is roughly 50 billion yuan [6]. As a result, this revealed that the investor systems for private equity firms still had weaknesses. The eligible investors referred that the investors had risk management and affordability, as well as specific assets and the particular income level. According to our country's current legal provisions, private equity funds must satisfy the limitations of the number of people to issue normally and legally protected by law. Still, this provision is only restricted to the number of people, and there is no additional clarification of eligible investment institution in the market [7].

\subsection{The related laws and legislations are incomplete}

At the moment, China's private equity fund withdrawals related supervision is imperfect. Judicial practice is limited, resulting in many specific legal obstacles in the withdrawal process for private equity funds. These series of legal obstacles constitute two levels of legal quandaries: The first is that a conundrum caused by the inefficient multi-level capital market system. This results in no acceptable market for private equity funds to depart or cannot enter the right market to exit. The second is the issue produced by the unseasonable design of the unique system of each capital market. As a result, when it comes to exiting, private equity funds face numerous challenges.

One of the major problems in our country is that the main exit strategy for private equity funds exits from investment enterprises mainly in IPO-oriented channels. Research shows that private equity firms supported Chinese companies going public in 2011 with 171 funding snouts totalling $\$ 29.5$ billion, while the number of listings and financing amounts in 2010 was greater [8]. Since many aspects of our country's capital market are in limited supply, the local market fails to satisfy the private equity funds seeking to exit their investments. Therefore, a number of private equity firms have turned to the international market. In addition, there are some problems related to private placement information disclosure.

\subsection{Current difficulties of private equity funds in tax policy}

The policies of private equity funds are continuing to improve as the number of investment modes increases. However, despite the implementation of various policies to support private equity funds in China, there are still some issues with the relevant policies of private equity funds in China when compared to the practical development scenario of private equity funds in recent years [8].

Firstly, each city has different policies related to tax. However, according to different tax items, local regulations are not consistent in each city, and the tax rates are also correspondingly different. For instance, in Beijing, Shanghai, and Shenzhen, which equity investment funds develop well in China, if investors expect to invest in these cities, they tend to need to comply with local regulations on private equity funds. Since each city has its own policy for the taxpayers, this may lead to private equity is hard to develop in a single way. Therefore, this might be difficult for the state and regulators to govern the collection of taxes, and it might not be favourable to unified growth for private equity funds themselves. 
Secondly, the ultimate taxes paid are inconsistent for the same individual investors due to their choice of different organizational structures. Under the various organizational structures, the policy of collecting comparable income tax is contradictory. According to 'corporate income tax' and 'individual income tax', individual investors are more likely to face a wide range of tax burdens due to different types of organizational structures [9]. When the equity exit income is transferred, the business system is required to pay corporate income tax at a rate of $25 \%$. Following distribution to individual investors, the company system is also required to pay personal income tax at a rate of $20 \%$. However, individual investors in limited partnership funds only need to pay a $20 \%$ tax on the revenues of stock transfers generated from distribution [10]. This might give rise to no regulatory obligations in existence. Since private equity investment funds have a broad reach and include several ministries, including the Development and Reform Commission, the China Banking Regulatory Commission, and the China Securities Regulatory Commission, they combine fund raising and investing operations. The monitoring obligations of government agencies overlap or are not clearly defined under this distinct supervision system based on institutional supervision. This has become a barrier to the growth of private equity investment funds.

\section{THE REASON FOR THE PRIVATE EQUITY FUNDS' LEGAL DILEMMA}

\subsection{China private equity fund market status and analysis in 2020}

In 2020, China's private equity market became the Asian-Pacific region's dominant market in terms of both transaction volume and volume. Over the past year, the number of private equity deals in China reached $\$ 97$ billion, while the number of exits and funds in the AsiaPacific region fell to $\$ 46$ billion and 179 over the same period. It is worth mentioning that the sector has attracted increasing investor interest and attention in 2020 thanks to the positive correlation between environment, social and corporate Governance (ESG) [11]. Based on these data, we can see that despite the severe impact of COVID-19 on the global economy and the private equity market, the Chinese market recovered rapidly and reached a new high in the whole of 2020 and showed an upward trend. However, compared to the same period in the Asia-Pacific region, exit volume and the number of funds are significantly declining. China's rapid rebound has been driven by strong demand and investment in key industries. Thus, it can be seen that the demand for private equity funds in China is huge.

\subsection{The main reasons for the lack of laws related to private equity funds in China and the comparison with the perfect legal system in the United States}

The resource supply of the legal system does not match the market demand of the market economy. The main reason why private equity funds encounter difficulties is that China's laws and regulations on private equity funds are not perfect. This imperfect legal system can keep up with the demand of the private equity fund economic market and lead to the absence or dislocation of the supervision of the relevant regulatory authorities. Therefore, it is harmful to private equity in China.

China's lack of laws related to private equity funds is mainly due to China's traditional legal model -- policy first and law lagging behind. In China, regulatory policies are introduced firstly, and only when the application of regulatory policies is mature will they become laws. In this long process, this feature led to the legal supervision is not in place, the lack of specific laws and regulations and legal provisions vague and other problems. Therefore, China's current provisions on private equity funds are mostly made by departments and a few laws and regulations. However, these laws and departmental regulations are insufficient for China's large and growing economic market.

First of all, the Civil Code regulates private equity funds. The Civil Code adjusts the standard terms of private equity fund contracts, expands the scope of standard terms identification, enhances the provider's obligations of standard terms, and raises the requirements for fund managers to formulate and sign fund contracts or LPA. So private-equity managers also need to expand the range of format clauses, such as "expense", "profit distribution", "dispute resolution", even including investment, exit, such as information disclosure to investors may cause significant stakes in the main contract terms for tips and instructions, avoid terms not included in the contract or is invalid. Secondly, "the Fund law" in 2012 also included public funds in the scope of adjustment for the first time. Still, it did not establish a separate private equity fund manager registration system, qualified investors, and the private equity fund products for the record, promotion, fund custody, and prohibitive provisions to clarify the essential clauses in the contract. However, as the main regulated object of the Fund Law was the public offering fund, only the principal provisions were made for the private equity fund, and there was no legal basis for the private equity investment fund, which had become a new force among the professional, institutional investors. In addition, private funds lacked clear legal status driven by market demand. "Lack of Securities investment Funds", "Securities Law", and "Trust Law" did not make clear provisions on the meaning of private funds, sources of funds, organization mode, operation mode and so on. 
Compared with other countries such as the United States, it had a mature regulatory system and perfect legal system in terms of private equity funds. At present, The United States has established the Securities Act of 1933, Investment Company Act of 1940, Regulation D, Rule 144A, Securities Exchange Act of 1934, Investment Advisors Act of 1940, National Securities Market Promotion Act of 1996, American Venture Capital Association Trading Standards, and Dodd-Frank Act As the core of the private equity supervision legal system. Its regulatory focus includes the exemption conditions for the registration of private offering of securities, the qualification and registration conditions of fund managers, as well as record keeping and information disclosure, prevention of abuse of non-public information, anti-fraud and so on. Therefore, china's imperfect laws and regulations have become the main reason why private equity funds encounter difficulties in China's development.

\section{CHINA'S APPROACH TO THE DILEMMA FACING PRIVATE EQUITY FUNDS}

\subsection{Qualified investors}

To eliminate the dilemma caused by the immaturity of the current legal system, private equity funds should be strictly regulated to protect investors and prevent systemic financial risks. Qualified investors are the cornerstone of the private equity market. Therefore, it is urgent to establish a Qualified investors system. Qualified investors refer to those who have the ability to identify and bear risks. The main identification criteria are the investor's asset status, especially the financial asset status, supplemented by the investor's investment experience and professional ability. Qualified investors theory originated from the Securities law of the United States. The government must regulate the transactions between securities issuers and ordinary investors to protect the public from fraud and maintain market order. The regulatory means require publicly issued securities to register with regulatory agencies and mandatory public disclosure of information to provide ordinary investors with sufficient opportunities to assess the value of securities investment. First of all, I think the government should regulate the transactions between securities issuers and ordinary investors to protect the public from fraud and maintain market order. The regulatory means is to require publicly issued securities to register with regulatory agencies and mandatory public disclosure of information to provide ordinary investors with sufficient opportunities to assess the value of securities investment. Secondly, as China is a populous country, its citizens' income levels and assets vary widely. Therefore, issuers of different private equity fund institutions should understand customers' financial status, knowledge and skills, investment experience and risk preference, understand the fund products themselves, and recommend appropriate fund products or services to customers based on their information. Moreover, when investors know the information about private equity that regulators force them to disclose publicly, they have the assets and the capacity to do so. The establishment of relevant regulatory departments, strict supervision of each step of the transaction, and critical moment giving investors relevant advice and publicity of some relevant knowledge can protect investors. That would get private equity out of its current predicament.

\subsection{Improvement of private equity legislation}

Laws should be updated on a technical level, and private equity investment fund requirements should be implemented as soon as possible. In the developed private equity sector, financial institutions are the most significant investors. Therefore, based on a complete understanding of the risks associated with equity investment, the government should consider lowering the requirements for domestic financial institutions, social security funds, and large state-owned enterprises to invest in equity investment funds and allows the preceding institutional investors to participate and determine whether or not to invest in private equity funds.

In addition, a simple exit mechanism enables private equity funds to employ money of high quality and efficiency. Our country's main board market, SME board market, and chinext market are all established at this time. This creates a route for the withdrawal of private equity money. However, most firms in which PE funds participate are non-listed, and the development and strengthening of multi-level capital markets are more important to the withdrawal of PE funds. It offers effective information for PE funds to participate in nonlisted businesses. It clears the entrance and exit channels of PE funds by creating an equity investment and financing information platform.

Due to our country's capital market's late start and lack of growth, proper legislative protection should encourage relevant mature investors with market investment capacity and risk tolerance to join private equity investment and safeguard those who are risk-conscious and resistant. This promotes unified administration, uniform identification and eliminates legal, regulatory overlap. Two improvements will probably help to improve the legal oversight of private equity funds [12] On the one hand, it is important to clarify authority power and construct a regulatory model with the China Securities Regulatory Commission as the primary accountable agency. On the other hand, improving the internal governance structure of private equity funds and standardize the organizational form and agreements of private equity funds. 


\section{CONCLUSION}

In conclusion, this essay aims to show the significant meaning of improvements in China's capital market through evaluating the current situation of private equity in China. Throughout this essay, the current situation of private equity in our country has been discussed to evaluate the difficulties and causes of the legal dilemma. Meanwhile, there have been suggested some improvements to develop well in future. Compared with other developed countries, the multi-level capital market in China is still under construction, and different institutions and procedures have not yet matured. China now has the largest private equity fund market in Asia. Private equity funds are an essential source of funding for my country's innovation and growth. Private equity funds will undoubtedly play a larger part in the country's economic development as relevant processes in my country are strengthened and standardized.

\section{REFERENCES}

[1] Wang Lei, Shi Ping (2008), The development status quo of private equity investment in China is explored. Journal of Xi'an University of Electronic Science and Technology (Social Science Edition), vol.18 (2), 74-77.

[2] Zhao Lei (2019), Research on the Legal Organization of Private Equity Investment Funds in China, Master's thesis, China University of Political Science and Law.

[3] Wan Lu (2010), An analysis of the source of funds for private equity funds in China. Vocational Technology, vol.09, 84-85.

[4] Jenkinson, T (2008), Book The development and performance of European private equity.

[5] Barros, P. P., Berglöf, E. et al. (2005), Integration of European banking: the way forward. Centre for Economic Policy Research, vol.03,1-50.

[6] Zhai Kai (2013), On the perfection of qualified investor system of private equity funds in China. Rule of Law and Society, vol.14, 92-93.

[7] Zhang Yichun, Lin Mushun (2012), Analysis of Preferences and Obstacles to the Exit Methods of Private Equity Funds in China. Modern Management Science, vol.09, 7-9.

[8] Tang Shi (2011), Research on the Taxation Policy of Private Equity Investment Funds in China, Master's thesis, Beijing Jiaotong University.

[9] Zhang Xueyong (2010). Discussion on the Taxation Policy of Private Equity Investment. Tax Research, vol. 06, 58-60.
[10] Liu Jinke, Yang Wenlan (2016), Research on the Tax Policy of Private Equity Funds in China. Tax Research, vol. 06, 58-62.

[11] Global Private Equity Report 2021,2021.

[12] Xue Jie (2011), The problems and countermeasures in the development of private equity funds in China. Special Economic Zone, vol. 01, 130-131. 